\title{
Use of Electronic Resources in Teaching and Learning at Federal University, Dutsin-Ma, Nigeria
}

\author{
Hajara Yakubu (Mnla, Cln) \\ Principal Librarian, Federal University, Dutsin-Ma, Katsina State, Nigeria \\ Email: hyakubu@fudutsinma.edu.ng; yhajara69@yahoo.com \\ Olatoye, Olufunke Omotoke \\ Department of Educational Foundations and Curriculum, Faculty of Education, \\ Ahmadu Bello University, Zaria, Kaduna State, Nigeria \\ Email: odunsi_olufunke@yahoo.com; olufunkeolatoye.oo@gmail.com
}

\section{Doi:10.5901/mjss.2015.v6n1p584}

\section{Abstract}

The advent of Information and Communication Technology (ICT) has paved way to many things hitherto undiscovered, electronic resources inclusive. Subscription and annual licensing and renewal of electronic resources are one thing and maximum utilisation of them is another aspect entirely. This paper examines the possibility of subscribing to e- resources and onward payment of annual license fee for staff and students utilisation of e- resources so as not to waste financial and academic resources of Federal University, Dutsin-Ma (FUDMA). Questionnaire was designed. Data were collected and analysed, using frequency count, percentages and charts. Most FUDMA academic staff (98\%) have their personal e-mail addresses and use e-mail $91 \%$ 'very frequently'. The paper concludes that FUDMA community generally, is not only aware of e-resources but utilising them to best of its ability and more needs to be done. Therefore, improvement should be intensified in power supply, increment in bandwidth, optic fibre cables, subscriptions of both online and offline databases, among others.

Keywords: e-resources, teaching, learning, library, university.

\section{Introduction}

Change is constant. The birth of Information and Communication Technology (ICT) has drastically affected library services and resources. It has transformed the quest for knowledge in different dimensions, not necessarily through the conventional formats. This culminates into intranet and internet. Electronic resources are information on devices such as net, hard disc, flash drive and CD ROMS. It could be in form of database application created for a particular organisation that manages data and allows easy access, fast storage and retrieval of that data. Database can be edited to suit one's purpose or interest.

E-resources could be accessed via the aid of user name and password while some are based on the availability of infrastructural facilities and powerful network connectivity. Sharma (2009) opines that advances in computer application during the past few decades have brought radical changes in the way information is gathered, stored, organised, accessed, retrieved and consumed. Librarianship originally known as a trinity of acquisition, organisation and dissemination of print media in traditional ways has transcended and changed in recent times into acquisition, organisation, collection development, services and resource management. E-resources have become part and parcel of library services, with particular reference to Federal University, Dutsin-Ma (FUDMA) as one of the ICT-driven institutions. Ahiazu (2012) emphasised that the ICT-driven transformation from librarianship to library and information science comes with changes in the learning, teaching and research environment and changes in the behaviour of library users. Therefore, there is the need to provide electronic resources and services which are maintained alongside the conventional resources and services.

Academic libraries are libraries found in higher institutions of learning. These include universities, polytechnics and colleges. The mission of academic library is to support teaching, learning and research of its parent institution via the provision of current, reliable and relevant materials that are well-organised for easy accessibility. Curzon (2010) opines that providing support for teaching, learning and research is the focus of a good library. To help in this regard, the library collections should be rich and diverse. Federal University, Dutsin-Ma as an ICT-driven baby institution born in the era of 
information technology has to embrace innovation. In this, its library as an indispensable component cannot be left out. It has to go extra mile in providing materials suitable to courses offered by the parent institution both in print media and electronic resources.

\subsection{Historical Background of Federal University Dutsin-Ma}

The Federal University Dutsin-Ma (FUDMA) came into limelight in 2010 through the approval of the Federal Executive Council for the establishment of nine new Federal Universities. Federal University, Dutsin-Ma is situated along Kankara and Katsina Road, sixty kilometers away from Katsina town in Katsina State. The Universities are established for the purpose of increasing access to university education and ensuring universities in Nigeria reflect the spirit of Federal Character. Federal University Dutsin-Ma was the first among the nine new federal universities to commence academic activities. The university took off on 14th July, 2012 with pioneer students that matriculated on Monday $30^{\text {th }}$ July, 2012 and the third set of students matriculated on $17^{\text {th }}$ December, 2013.

\subsection{Vision and Mission of Federal University Dutsin-Ma}

The vision of the university is "To be a top ranking world class university, committed to excellence in research and the production of a generation of leaders with passion for service". The mission of the university is "To create knowledge, impart it to transform human beings, deploy it to grow the economy and solve local and global challenges, and do so in partnership and with integrity" (Abubakar, 2013).

Some Online Activities in Federal University, Dutsin-Ma

Below are examples of online activities taking place in FUDMA;

* Uploading and downloading of lecture notes.

* Conduct of Computer-Based Test (CBT) of $1^{\text {st }} \& 2^{\text {nd }}$ continuous assessment and examinations for both regular and remedial students.

* Conduction of post-UTME entrance examination.

* All staff and students own an institution's email whereby they communicate and exchange information freely. For example: hyakub@fudutsinma.edu.ng

* Some staff often give students assignments through email and must be submitted back through same.

- Reading of e-library materials (books and journals).

* Reading of newspapers.

* Registration of library users.

* Checking in and checking out library materials.

* Tracking overdue books and defaulters.

\subsection{Statement of the Problem}

The essence of university library is to act as an auxiliary to the parent institution. It is to support the learning, teaching and research of both staff and students through the provision of current, relevant and reliable materials that enhance their intellectual development. Electronic resources cannot be subscribed to, if properly utilised. Maximum utilisation encourages subsequent renewal of licenses. As a baby institution, FUDMA is growing in terms of faculty expansion, creation of new departments, students' enrolment, development of infrastructural facilities and information needs.

The e-resources available at FUDMA are mainly free e-books and e-journals. These include free library (FL), Open Course Ware (OCW) at Massachusetts Institute of Technology (MIT), Khan Academy (KA, basically video lectures) and Online Public Access Catalogue (OPAC).

The crux of the matter is that, there is a clarion call and urge by some FUDMA academic Staff that the library should subscribe to e-resources. This is the subject of discussion. How frequent is FUDMA academic staff using the existing ones for their research and other academic activities? This study therefore sought to find out the use of electronic resources in teaching and learning by Federal University, Dutsin-Ma academic staff.

\subsection{Research Questions}

The following issues were addressed to guide the study:

1. What percentages of FUDMA academic staff have personal email address? 
2. How frequent do FUDMA academic staff use email?

3. How frequent do FUDMA academic staff use e-resources?

4. What is the impact of e-resources on academic staff teaching and learning?

5. What activities do respondents use e-resources for?

6. What are the types of e-resource data base preferred by FUDMA academic staff?

7. What are the factors that influence respondent choice of data base?

8. What are the problems associated with accessing e-resources at FUDMA?

\subsection{Significance of the Study}

Meeting the information needs of users requires the provision of the actual information resources and services that satisfy their needs. This is paramount as it is the duty of library professionals to conduct periodic study of library users to evaluate their satisfaction with the available resources with a view to repackaging their services and resources for national development

The study will be useful to library staff and its users in selecting some specific e-resources that will be germane to their research and academic activities on or outside campus. It will identify the variables in the use of electronic resources by FUDMA academic staff and students. It will give the librarian and university management useful knowledge that can be helpful in the subscription and onward renewal of licenses to e-resources without FUDMA resources being wasted.

\subsection{Scope of the Study}

The study is streamlined towards the use of electronic resources by academic staff of Federal University, Dutsin-Ma, Katsina State. The reason is that they lecture, forms notes and are involved in the selection process of FUDMA library collections.

\subsection{Limitation}

The study is restricted to FUDMA academic staff only. Due to time constraint and limited resources, the researcher could not cover the entire FUDMA staff and students. However the results of the findings will be analysed and generalised to all the staff at FUDMA.

\section{Literature Review}

Electronic resources are no longer new in modern libraries. They have become part and parcel of library services. Then, what are electronic resources? E-resources have been variously defined by scholars of Information and Communication Technology (ICT). Electronic resources are information that is stored in digital formats. Ahiazu (2012) opines that eresources are information that is available in electronic or digital formats. These include e-books, e-journals, digitalized primary sources, statistical sources and other computerised electronic resources. E-resources are in library without walls. Ahiazu (2012) also stresses on the comfort derived by users of e-resources. She said that.

"Users sit in the comfort of their homes, classroom, tube stations, Public transport buses, holiday parks and sea beaches to access their university library resources, so long as they possessed thecampus address and passwords".

E-resources can also be defined as a collection of online publications giving all the bibliographical description of a book such as author, title, ISBN, edition, date and place of publication, publisher, pagination, series and some idea of the content' http://www.Isbu.ac.uk/library/html/jargon.shtul. 'It is an information on internet. Information (usually a file) which can be stored in the form of electrical signals usually, but not necessarily on computer' www.allwords.com/word-electronic resources.html.

Another author, Reitz (2004) de electronic resources as, Materials consisting of data and / or computer program(s) encoded for reaching and manipulation by a computer operator by the use of a peripheral device directly connected to the computer or remotely via a network such as the internet.

Sharma (2009) emphasised on the importance of e-resources to distant learners as.

"Helpful to distant learners who have limited time to access the libraries from outside by dial-up access to commonly 
available electronic resources, mainly CD-ROM, OPACs and Internet, which are replacing the print media".

From the definitions above, it can be deduced that electronic resources share some characteristics with prints in the following:-

Convey messages, ideas, information and facts.

- Have bibliographical details of an entity.

- Accessibility is easy.

- Aids in research.

- Electronic resources overcome geographical limitation.

- Many researchers can use e-resources of the same title at the same time and at different locations.

However, e-resources cannot be accessed without the institution's user's name and password given to an individual.

\section{Methodology}

\subsection{Research Design}

The descriptive survey method was used. In this type of design, data is usually collected from a small group of people while the findings are generalised to whole population. This study sought to explore the use of e-resources by the academic staff of Federal University Dutsin-Ma. The data collected are the reflection of the information on the use of electronic resources by the FUDMA academic staff.

\subsection{Population for the Study}

The targeted population for this study three hundred and one (301) academic staff so far employed as at the time of this study. Respondents were drawn from among the three faculties. There are twenty two Departments in these faculties. The breakdown of the sample size is illustrated in table 1 below:

Table 1: The breakdown of the sample size

\begin{tabular}{|c|c|c|c|c|}
\hline S/No. & Faculty & Population & Sample Size & Cumulative \\
\hline 1 & FAAT & 77 & 33 & 33 \\
\hline 2 & FAMSS & 117 & 34 & 67 \\
\hline 3 & FSE & 107 & 33 & 100 \\
\hline
\end{tabular}

Key: FAAT=Faculty of Agriculture and Agricultural Technology, FAMSS=Faculty of Arts, Management and Social Sciences, FSE=Faculty of Science and Education

\subsection{Sample Size and Sampling Technique}

The technique used in drawing the sample size of this study is simple random sampling technique. This method of sampling ensures that each member of a population has an equal chance of being selected.A sample of one hundred academic staff was selected to participate in the study.

Table 2: Gender

\begin{tabular}{|c|c|c|c|}
\hline Respondents & Frequency & $\%$ & Cumulative \\
\hline Male & 87 & 87.0 & 87.0 \\
\hline Female & 13 & 13.0 & 100.0 \\
\hline Total & 100 & 100.0 & \\
\hline
\end{tabular}

Table 3 shows that $13 \%$ of the respondents were females while $87 \%$ were males. This is a clear indication that in FUDMA, the number of male staff outnumbered that of female. 
Table 3: Ranks of Academic Staff Selected for the Study

\begin{tabular}{|l|c|c|c|}
\hline Respondents & Frequency & Percent & Cumulative \\
\hline Professor & 8 & 8.0 & 8.0 \\
\hline Associate. Prof. & 5 & 5.0 & 13.0 \\
\hline Senior Lecturer & 10 & 10.0 & 23.0 \\
\hline Lecturer I & 11 & 11.0 & 34.0 \\
\hline Lecturer II & 18 & 18.0 & 52.0 \\
\hline Assist. Lecturer & 31 & 31.0 & 83.0 \\
\hline Graduate Assist. & 17 & 17.0 & 100.0 \\
\hline Total & 100 & 100.0 & \\
\hline
\end{tabular}

Table 3 indicated $8 \%$ of the respondents were Professors, 5\% were Associate Professors, $10 \%$ were Senior Lecturers, $11 \%$ were Lecturer I, 18\% were Lecturer II while 31\% and 17\% were Assistant Lecturers and Graduate Assistants, respectively. It is amazing to have a baby institution with such timbers and calibres of academic scholars especially Professors who are very hard to come by. This is just a few of them. FUDMA is coming up in a grand style.

\subsection{Research Instrument}

Questionnaire was used. Questionnaire according to Sambo (2005), is a research instrument that consists of a set of questions on a specific subject under investigation to which the participants in a study are expected to respond.

\subsection{Data Administration and Collection Procedure}

The questionnaire was distributed to various departments by the researchers. The collection was done with the aid of research assistants.

\subsection{Data Analysis}

Descriptive statistical analysis was used. Percentages were generated; tables and charts were drawn where necessary.

\section{Results}

Research Question 1: What percentages of FUDMA academic staff have personal email address?

Table 1: Ownership of e-mail address by respondents

\begin{tabular}{|c|c|c|c|}
\hline Response & Frequency & Percent & Cumulative \\
\hline No & 2 & 2.0 & 2.0 \\
\hline Yes & 98 & 98.0 & 100.0 \\
\hline Total & 100 & 100.0 & \\
\hline
\end{tabular}

The table shows that all FUDMA academic staff have e-mail addresses except $2 \%$ of the respondents that were yet to open theirs. One thing is certain, as an ICT driven Institution, all the staff were registered with e-mail addresses.

Research Question 2: How frequent do FUDMA academic staff use email?

Table 2: Frequency of Use of e-mail by FUDMA Academic Staff

\begin{tabular}{|c|c|c|c|}
\hline Response & Frequency & Percent & Cumulative \\
\hline Very Frequently & 71 & 71.0 & 71.0 \\
\hline Frequently & 23 & 23.0 & 94.0 \\
\hline Not Frequently & 5 & 5.0 & 99.0 \\
\hline I don't use it at all & 1 & 1.0 & 100.0 \\
\hline Total & 100 & 100.0 & \\
\hline
\end{tabular}



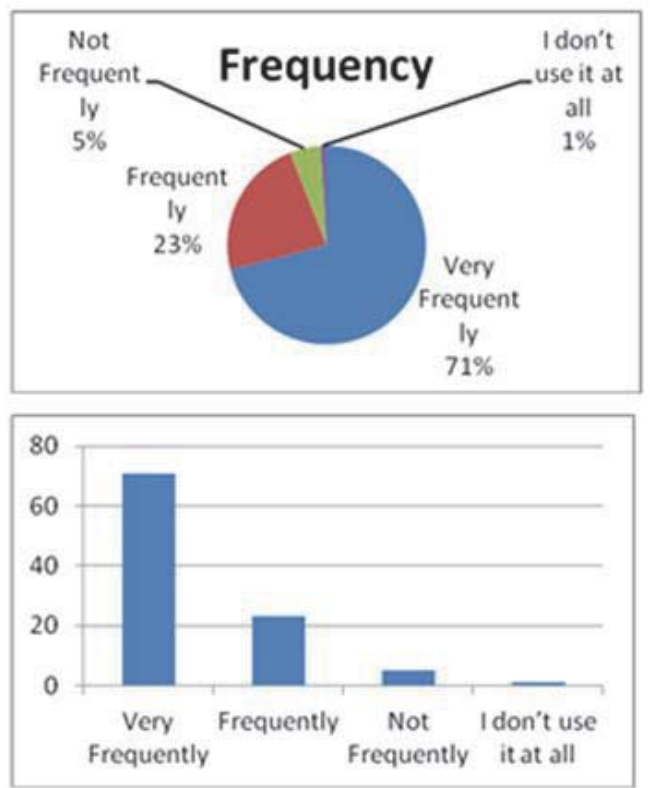

In table $2,71 \%$ of the respondents used e-mail very frequently, $23 \%$ frequently, $5 \%$ of staff are not using it frequently while $1 \%$ is not using it at all.

Research Question 3: How frequent do FUDMA academic staff use e-resources?

Table 3: Frequency of Use of e-Resources

\begin{tabular}{|c|c|c|c|}
\hline Responses & Frequency & Percent & Cumulative \\
\hline Daily & 76 & 76.0 & 76.0 \\
\hline Weekly & 20 & 20.0 & 96.0 \\
\hline Monthly & 3 & 3.0 & 99.0 \\
\hline Not at all & 1 & 1.0 & 100.0 \\
\hline Total & 100 & 100.0 & \\
\hline
\end{tabular}

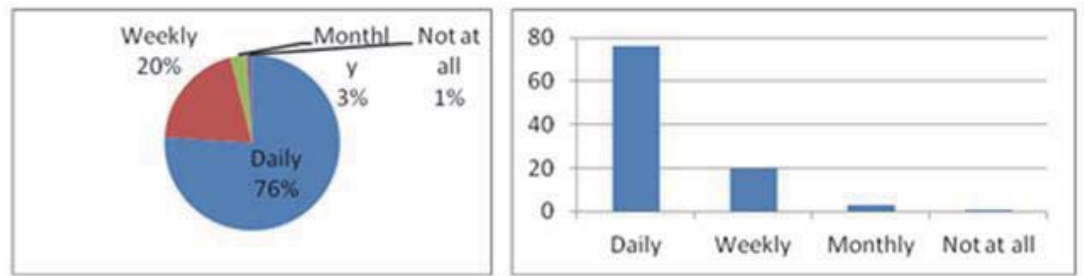

The above table reveals that $76 \%$ were using e-resources on daily basis, $20 \%$ used them once in a week while $3 \%$ used them monthly or while 1\%respondent does not it at all. Since close to $80 \%$ of the respondents were using e-resources daily, is an indication that FUDMA scholars are aware of e-resources and utilise them in teaching and learning.

Research Question 4: What is the impact of e-resources on academic staff teaching and learning?

Table 4: Impact of e-Resources on Academic Staff Teaching and Learning

\begin{tabular}{|c|c|c|c|}
\hline Responses & Frequency & Percent & Cumulative \\
\hline Very Relevant & 88 & 88.0 & 88.0 \\
\hline Relevant & 11 & 11.0 & 99.0 \\
\hline Irrelevant & 1 & 1.0 & 100.0 \\
\hline Total & 100 & 100.0 & \\
\hline
\end{tabular}



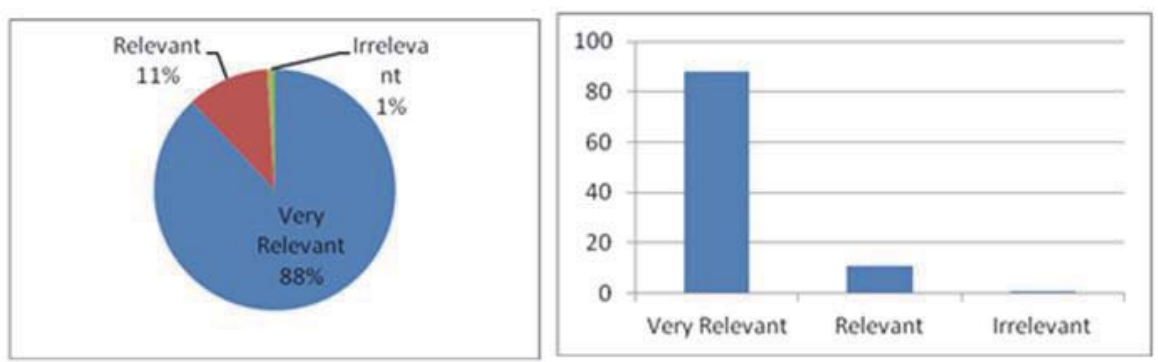

Table shows that $88 \%$ of the respondents indicated that e-resources are very relevant to them, $11 \%$ indicated relevant and $1 \%$ marked irrelevant. From this analysis, it shows that e-resources are very relevant in teaching and learning.

Research Question 5: What activities do respondents use e-resources for?

Table 5: Some Specific Activities of E-Resources

\begin{tabular}{|c|l|c|c|c|}
\hline S/N & Activities & Yes (\%) & No (\%) & Total \\
\hline 1 & Developing Lecture Notes & 92.0 & 8.0 & 100 \\
\hline 2 & Research Work & 90.0 & 10.0 & 100 \\
\hline 3 & Personal Study for Self Improvement & 79.0 & 21.0 & 100 \\
\hline 4 & Teaching & 72.0 & 28.0 & 100 \\
\hline 5 & Reference Purpose & 67.0 & 33.0 & 100 \\
\hline 6 & Entertainment & 31.0 & 69.0 & 100 \\
\hline 7 & Sport & 27.0 & 73.0 & 100 \\
\hline 8 & Religion & 41.0 & 59.0 & 100 \\
\hline 9 & News & 22.0 & 78.0 & 100 \\
\hline
\end{tabular}

From the above table, it shows that $92 \%$ of the respondents developed their lecture note through e-resources while $8 \%$ did not; $90 \%$ used them for research work; $79 \%$ used e-resources for personal improvement and $21 \%$ did not; $72 \%$ implored e-resources in teaching whereas $28 \%$ never bothered. The data also revealed that $67 \%$ consulted eresources for reference purpose and 33\% do not. Majority of the academic staff were not using e-resources for entertainment, sport, religion and news as indicated on the table.

Research Question 6: What are the types of e-resource data base preferred by FUDMA academic staff?

Table 6: Types of E-Resource Data bases Recommendation

\begin{tabular}{|l|c|c|c|}
\hline Responses & Frequency & $\%$ & Cumulative \\
\hline Online only & 47 & 47 & 47.0 \\
\hline Offline only & 11 & 11 & 58.0 \\
\hline Both online and offline & 42 & 42 & 100 \\
\hline Total & 100 & 100 & \\
\hline
\end{tabular}

From the above, it could be deduced that $47 \%$ recommended online databases, $11 \%$ opted for offline only while $42 \%$ preferred both online and offline.

Research Question 7: What are the factors that influence respondent choice of data base?

Table 7: Reasons for the choice e-Resource Databases

\begin{tabular}{|c|l|c|c|c|}
\hline S/N & Reasons & Yes (\%) & No(\%) & Total \\
\hline 1 & Use internet at home without connectivity & 50 & 50 & 100 \\
\hline 2 & Power outages & 42 & 58 & 100 \\
\hline 3 & Bad network services & 48 & 52 & 100 \\
\hline 4 & Use mobile device to download & 58 & 42 & 100 \\
\hline 5 & Can access e-resources in my office & 54 & 46 & 100 \\
\hline 6 & Prefer going to the Library to access e-resources & 7 & 93 & 100 \\
\hline
\end{tabular}


The analysis of this table justifies their reasons for whichever databases preferred. Half of the respondents prefer to access offline e-resources at home while half (50\%) did not; $48 \%$ chose offline due to power outages whereas $52 \%$ counteracted; $48 \%$ chose bad network services as one of the reasons for recommending online, offline or both while $52 \%$ felt that could not be the reason; those that recommended both (on \& offline) felt they could use their mobile device to download from e-resources as $58 \%$ indicated that whereas $42 \%$ declined; $54 \%$ claimed they can access e-resources in their offices and $46 \%$ declined in response; surprisingly, only $7 \%$ of the respondents prefer using the library for information accessibility while majority $93 \%$ declined

Research Question 8: What are the problems associated with accessing e-resources at FUDMA?

Table 8: Problems of Accessing E-Resources at FUDMA

\begin{tabular}{|c|l|c|c|c|}
\hline S/N & Problems & Yes (\%) & No (\%) & Total \\
\hline 1 & Information Over load & 12 & 88 & 100 \\
\hline 2 & Download delay & 74 & 26 & 100 \\
\hline 3 & Problem with credibility of information & 20 & 80 & 100 \\
\hline 4 & Inability to find information & 16 & 84 & 100 \\
\hline 5 & Poor skills for operation & 22 & 78 & 100 \\
\hline 6 & Power outages & 70 & 30 & 100 \\
\hline 7 & Poor network connectivity & 88 & 12 & 100 \\
\hline 8 & Inaccessibility of some websites & 47 & 53 & 100 \\
\hline 9 & Indifferent attitudes of library staff & 2 & 98 & 100 \\
\hline 10 & Limited number of systems & 12 & 88 & 100 \\
\hline
\end{tabular}

The above table shows that $12 \%$ agreed to information over load, $74 \%$ confirmed that there is delay in download, $20 \%$ agreed that credibility of information is not ascertained while $80 \%$ disagreed, $16 \%$ of the respondents indicated inability to find information whereas $84 \%$ disagreed to this challenge, which means inability to find information is not a problem to FUDMA academic staff in using e-resources.22\% showed that they have poor skills for operation and interestingly, $78 \%$ disagreed to the statement .

This confirms the fact that FUDMA as an ICT driven University, most of its staff are ICT compliant, $70 \%$ of the respondents revealed that there is power outages while 30\% declined. In Nigerian society, power failure or erratic power supply has been the order of the day not peculiar to libraries.88\% reported poor network connectivity whereas $12 \%$ disagreed; $47 \%$ agreed to inaccessibility to some websites and $53 \%$ disagreed. Amazingly, only $2 \%$ testified to indifferent attitudes of library staff towards library users whereas $98 \%$ of the respondents overwhelmingly affirmed. This is so because FUDMA library staff is very dedicated with passion to the service of humanity.

Finally, on the issue of limited number of systems, $12 \%$ of the respondents agreed while $88 \%$ disagreed because virtually all FUDMA staff and some students own their laptops where they can access library resources online or offline.

\section{Concluding Remarks and Recommendations}

The study reveals that the use of electronic resources in teaching and learning among is common the academic staff of Federal University, Dutsin-Ma. As an ICT- driven institution, most of its academic staff are computer literate.

However, they need training and retaining on the use of electronic resources in order to develop themselves and utilise it in imparting knowledge to students, in this era of ICT. Infrastructural facilities such as electricity, internet connectivity, servers, software applications for fast track of websites, database, are the prerequisite to electronic resources.

Computer and ICT training is very important in raising the level of computer utilisation (Olatoye, 2011). Computer anxiety is also a major cause of under utilisation of computers. One of the ways of overcoming computer anxiety is to possess a computer system (Ogunkola \& Olatoye, 2008; Olatoye, 2009). Continuous training in E-learning is important to improve the way staff use ICT facilities.

The following recommendations were made for the improvement and way forward on the utilisation of e-resources:

* There should be constant power supply and external power sources such as solar energy and inverter so as to curtail the problem of power outages.

* Strengthening the available network in order to be stable and reliable for ease of access to websites.

* Regular upgrading of systems is required and service overhaul of the ICT centre to improve the e-resources at 
FUDMA.

* Creation of 24-hour browsing cafe for both staff and students

* Sensitisation, that is, proper, rigorous and continuous training and retraining of FUDMA staff and students on the use e-resources. This could be done through seminars workshops and symposia.

* Increase of broad bandwidth that guarantees easy access anywhere, anytime.

* Online and offline database resources should be made available to all staff and students.

* Collaborative efforts should be intensified with other higher institutions of repute to harness their e-library resources through inter-libraries networking.

* Provision of Uninterrupted Power Supply (UPS) to guarantee the comfort of library users.

* Establishment of user-friendly website server and improvement in the download speed.

* There is need for installation of fibre optic cables, to enhance the capacity of servers.

\section{References}

Abubakar, M. Y (2013). The University Ethics and Etiquettes. A paper presented by the Registrar at the orientation programme for 2012/2013 fresh students of Federal University, Dutsin-Ma, Katsina State, Nigeria.

Ahiazu, B. (2012): The Evolving Role of the University Librarians in Nigeria: what we need to do. Trends in Library and Information Science in Nigeria: A Festschrift in Honour of Professor Sam E Ifidon. -Lagos: Elis Associates.

Curzon, S. C.(2010): Academic Libraries. Encyclopaedia of library and Information Science, 3rd ed. Vol. 1. - New York: Cizc Press.

Ogunkola, B. J. and Olatoye, R. A. (2008). Inter-Relationships among Computer Ownership, Attitudes and Literacy of Science Teachers in Ogun State, Nigeria, Journal of Applied Global Research, Vol. 1, Iss. 2, Pp.33-39.Published by Intellectbase International Consortium, Nashville, Tennessee, USA.

Olatoye, R. A.(2009). Influence of Computer Anxiety and Knowledge on Computer Utilization among Junior Secondary School Students, Electronic Journal of Research in Educational Psychology,Vol.10,154-159.

Olatoye, R. A. (2011). Level of participation in ICT training programmes, computer anxiety and ICT utilization among selected professionals. International Journal of Education and Development using ICT, The University of the West Indies, Bardados, www.editlib.org/p/42202/article_42202.pdf

Reitz, J. M. (2004): Dictionary for Library and Information Science. -London: Libraries Unlimited.

Sambo, A. A. (2005): Research Methods in Education. - Ibadan: Stirling Hordan Limited'

Sharma, C. (2009): Use and Impact of E-Resources at Guru Gobind Singh Indraprastha University (India: a case study). Available at http://southernlibrarianship.icaap.org/content/v10n01/sharma_c01.html 
